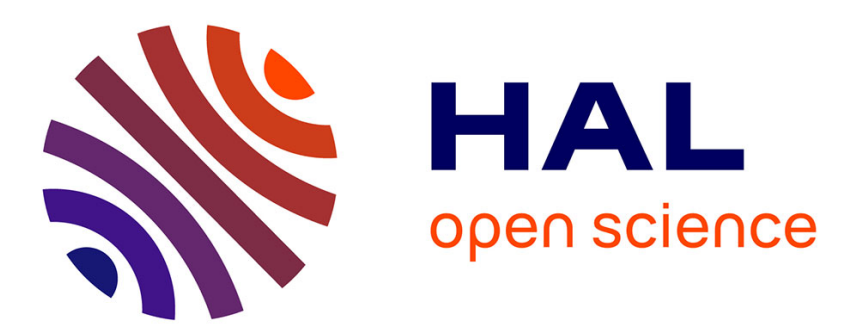

\title{
Back to Little Havana: Controlling Gentrification in the Heart of Cuban Miami
}

\author{
Marcos Feldman, Violaine Jolivet
}

\section{To cite this version:}

Marcos Feldman, Violaine Jolivet. Back to Little Havana: Controlling Gentrification in the Heart of Cuban Miami. International Journal of Urban and Regional Research, 2014, 38 (4), p.1266-1285. 10.1111/1468-2427.12097 . halshs-01223519

\section{HAL Id: halshs-01223519 \\ https://shs.hal.science/halshs-01223519}

Submitted on 2 Nov 2015

HAL is a multi-disciplinary open access archive for the deposit and dissemination of scientific research documents, whether they are published or not. The documents may come from teaching and research institutions in France or abroad, or from public or private research centers.
L'archive ouverte pluridisciplinaire HAL, est destinée au dépôt et à la diffusion de documents scientifiques de niveau recherche, publiés ou non, émanant des établissements d'enseignement et de recherche français ou étrangers, des laboratoires publics ou privés. 


\section{DRAFT UNDER REVIEW BY IJURR: Do not use without permission}

Title: Back to Little Havana: Controlling Gentrification in the Heart of Cuban Miami

Marcos Feldman (Florida International University)

FIU Center for Labor Research \& Studies

MM Campus LC 301

11200 SW 8th Street, Miami, FL 33174

Phone:305-348-2371

Email: mfeldman@fiu.edu

Violaine Jolivet (Université de Montréal)

Département de Géographie UdéM

520, chemin de la Côte-Ste-Catherine

Montréal (Qc), H2V 2B8, CANADA

Phone: 514-343-6111 \# 50181

Email: violaine.jolivet@umontreal.ca

Abstract: In this article we examine the nature and implementation of governing strategies to control the gentrification of Little Havana, the symbolic heart of Cuban Miami. We ask how Cuban-American power relations at the neighborhood level operate to "produce" the citizen best suited to fulfill and help reproduce policies and practices of "securing" in order to gentrify Little Havana. Based on long-term ethnographic research in Little Havana and Miami, our analysis reveals how governance operates through neighborhood-level intermediaries and interpersonal relations. We apply Foucault's "pastoral power" to Miami's Cuban exile community in order to explain how the "Cuban-ness" and "Latin-ness" of governing relations and the personification of political power are crucial to socio-spatial control in Little Havana. Elites shape the conduct of individuals in order to achieve strategic goals in the name of community interest. Residents are key partners in the relational ensemble that governs and disciplines the neighborhood comprised mostly of low-income, Central American immigrants.

Keywords: Spatial Governance, Pastoral Power, Gentrification, Cuban-Americans, Miami

Acknowledgements: This research would not have been possible without those who participated as respondents, informants or by providing access to archives and records. We would also like to thank Alex Stepick, Melissa Sanchez and Julie-Anne Boudreau for their encouraging feedback. And we are very grateful to the two anonymous reviewers for their insightful comments on earlier versions of the manuscript. 


\section{DRAFT UNDER REVIEW BY IJURR: Do not use without permission}

\section{INTRODUCTION}

Since its emergence as a "global city" and "capital of the Caribbean," a development significantly connected to the political-economic ascendance of the Cuban-American community (Sassen and Portes 1993; Grosfoguel, 1996; Nijman, 2000), Miami is described as a place that is "secure" and "stable" for investment in addition to the allure of its tropical climate, lifestyle and entertainment. The creation and maintenance of its perception as a safe place for investment and entertainment is achieved not only through the tools of urban placemarketing but also through administrative techniques of governance. Miami is unique in that the political administration, police forces and the criminal justice system are dominated by Cuban-American immigrants whose local power was achieved through mobilization against Castro’s island regime.

In this article we focus on the neighborhood of Little Havana, the symbolic heart of Cuban Miami. Using the metaphor of "pastoral power" (Foucault 2004) within the context of Miami’s Cubanía (Perez-Firmat 1997), we examine how Cuban-American leadership operates at the neighborhood level to "produce" the citizen best suited to fulfill and help reproduce local government's policies and practices of "securing" in order to "revitalize" Little Havana.

While gentrification has been analyzed in terms of the "revanchist" (Smith 1996) and "spatial manifestation of the new middle-class habitus" (Bridge 2001), here we focus on the sociospatial strategies of governance. By governance we refer to the growth machines of urban elites (Logan and Molotch 1987) and their entrepreneurial or neoliberal strategies (Harvey 1989; Brenner and Theodore 2002) but also to the "microphysics of power" (Foucault 1977) and the interpersonal and spatial techniques of government. In particular, we underscore the role of intermediaries - persons and institutions - as pivots that facilitate the circulation of 


\section{DRAFT UNDER REVIEW BY IJURR: Do not use without permission}

power in between the top (structure) and the bottom (subjects). These intermediaries are the decentralized and "indirect mechanisms [that] translate the goals of political, social and economic authorities into the choices and commitments of individuals” (Rose 1996, p. 58).

In this rapidly growing neoliberal city, territorial control of Little Havana is made possible by the history of Cubans' exile and political organization of the community. Little Havana was Cubans' gateway to Miami in the 1960s and 70s. As wealthier Cubans moved from this central neighborhood to the suburbs, they recouped the political and economic power they had lost in Cuba (Perez 1992). This ascendance enabled their control over Miami’s territories, the most important of which continues to be their initial “enclave” (Portes 1987) as it is the Cuban-controlled area closest to downtown real estate. The gentrification strategies revealed in Little Havana represent two important shifts: in the constitution of the Cuban-American “moral community” (Portes and Stepick 1993) from foreign affairs to increasingly local concerns; and in Cuban-American elites governing the neighborhood as residents and merchants to governing "at a distance” (Rose 1996, p. 43) through symbolic and policing techniques. While the symbolic techniques of marketing are applied through elites' commercial and political power, policing techniques are mobilized through a network of community and local state organizations comprising the Neighborhood Enhancement Team (NET), examined below.

Cuban-American "pastoral power" is fundamental to neighborhood-level policing and discipline. Typically in Foucauldian analyses the essence of pastoral power is not so much the "pastor" or personification of leadership but the construction and dissemination of "truths" that shape how people conduct their lives by helping them achieve well-being on earth: prosperity, health, security, and so forth (Foucault 1979, 1982). We argue that the "Cubanness” of Miami's pastorship and the personification of political power are essential to the legitimacy of these truths and to their circulation. Cuban pastorship reveals how elites 


\section{DRAFT UNDER REVIEW BY IJURR: Do not use without permission}

influence the conduct of residents in order to achieve strategic goals (social control to facilitate gentrification) in the name of individual and community interest. These elements elites, networks and associated ideas and techniques - form a "relational ensemble” (Jessop 2007) enabling the exercise of power. In drawing a schematic of this ensemble and examining its grassroots operations, we aim to understand how Cuban elites govern their symbolic territory to produce a gentrified Little Havana.

In relation to the common tropes of gentrification's racial/ethnic politics, Cuban-American elites occupy a double position: they are the external "White" and powerful majority gentrifying a neighborhood of mostly darker-skinned and lower-income Hispanics. But they are also insiders who share language and aspects of the immigrant experience ${ }^{2}$ with Little Havana residents, in addition to their patrimonial heritage in the symbolic center of the Cuban-American community. While gentrification is typically depicted as Whites displacing non-Whites, recent research on minority gentrifiers reveals a caretaking ethic which rationalizes gentrification through an ideology of racial/ethnic uplift (Lees et al. 2008, p. 109). Keeping it "inside" the community is deemed preferable to invasion by "White" outsiders (e.g., Dávila 2004; Patillo 2007; Boyd 2008). Despite arguments about the progressive impacts of the return of jobs and middle class role models to inner city neighborhoods (Wilson 1996; Freeman 2006), we believe, following others (Patillo 2007; Boyd 2008), that the discourse of pan-ethnic unity mistakenly homogenizes the needs and interests of all Hispanics.

The gentrification strategies found in Little Havana raise important questions about the role of race and ethnicity in neighborhood change but it is not our aim to answer these questions here.

\footnotetext{
${ }^{1}$ Ninety five percent of Miami-Dade County's Cuban-Americans reported their race as "White" in the 2010 Census.

${ }^{2}$ Like other Hispanics, Cubans leaders attribute their successes to hard work as immigrants who had to start over in the U.S. Unlike most other Hispanics, as political refugees Cubans receive preferential treatment under U.S. immigration policy.
} 


\section{DRAFT UNDER REVIEW BY IJURR: Do not use without permission}

Nor do we seek to analyze the extent of gentrification and its impacts, or capture the extent to which decentralized and personalized governing techniques operate in Little Havana. Rather, our analysis is concerned with the nature of the governing strategies and their implementation through neighborhood-level intermediaries. We present exemplary cases within an evolving scope of governance in order to understand how it works in the Miami context.

This article is based on ethnographic fieldwork conducted jointly by the authors as well as extensive periods of research conducted separately. ${ }^{3}$ Together, we completed seven interviews with respondents recruited through a purposive sample as well as a group interview with leaders of a Little Havana public housing residential association. ${ }^{4}$ We recruited interviewees who could provide insight into the governing strategies and practices of local elites. In addition to leaders' top-down perspectives, we sought the bottom-up views of residents. Interview respondents include the city district commissioner (1998-2008) and his staff, the longtime director of the Little Havana NET, a successful painter whose gallery and studio is on Calle Ocho, and two long-time residents and community activists. Most respondents are Cuban-Americans. To acquire a broader and historical context, we reviewed dozens of policy documents, newspaper articles, and the minutes of city commission meetings, and used GIS analysis of property sales and U.S. Census tract data to describe changes in the neighborhood. What follows is organized in two main sections. First we describe the context of gentrification in which governing takes place, focusing on the spatial practices integral to the commodification of the neighborhood's "insecure” and marginal spaces. Second, we develop

\footnotetext{
${ }^{3}$ The first author has lived in Little Havana for more than four years, engaged in research on gentrification in Miami (Feldman 2012) and in“action research” projects to address perceived injustices (see www.risep-fiu.org). The second author conducted research between 2006 and 2012 (11 months altogether) on the political geography of Miami's Cuban community (Jolivet forthcoming 2013). We have participated in and observed several neighborhood events, such as street festivals, political conferences, and meetings of city planning and community policing agencies, residential and merchant associations, and activist organizations.

${ }^{4}$ These women participated in a group interview for a separate research project (see Eisenhauer 2008).
} 


\section{DRAFT UNDER REVIEW BY IJURR: Do not use without permission}

our analysis of how Cuban-American "pastoral power" facilitates the neighborhood-level policing techniques applied to, and in partnership with, Little Havana residents.

\section{TAKING CARE OF LITTLE HAVANA: GENTRIFICATION AND SOCIAL CONTROL}

The neighborhood once known as Riverside was Cubans' primary residential gateway and a crucial base of political organization following the 1959 Cuban Revolution (Portes 1987; Forment 1989; Perez 1992). With the concentration of Cubans in Miami, Riverside became known as Little Havana and its main arterial roadway, Southwest Eight Street, became Calle Ocho.

As Cuban-Americans became established and moved to areas farther west from Miami's central city, increasing numbers of low-income residents and Central-American immigrants arrived in the eastern half of Little Havana, which became stigmatized as a ghetto (Gjebre 1980). Although Central-Americans now outnumber Cubans (Figure 1), the rules of spatial discipline are imposed by Cuban-American elites who act as the "historic owners" of the place. Cuban-Americans represent Little Havana politically and control key government and non-governmental organizations which shape daily life and economic activity in the neighborhood. The remaining, disproportionately elderly Cuban-Americans continue to make up an important voting bloc and crucial foundation for Cuban-American political control of the neighborhood (Shoer-Roth 2009). Welfare assistance and other social service agencies, crime watch groups, several public and private schools, the largest churches, and major residential, merchant and civic associations are managed by Cuban-Americans. In one of Little Havana's largest institutions, San Juan Bosco Church (known as "the exiles' cathedral"), Cuban-American church leaders strive to "inculcate [Central American parishioners] by policing their free health services and teaching the new arrivals' children 'proper' values in the after-school program... San Juan Bosco uses multiple forms of pressure 


\section{DRAFT UNDER REVIEW BY IJURR: Do not use without permission}

to assimilate Central Americans not to a White middle-class American mainstream model, but to a Cuban-American pattern” (Del Pino-Allen 2009, p. 149).

[Figure 1]

Little Havana is considered to be increasingly "ripe” for gentrification due to its proximity to downtown Miami (Figures 2 and 3) and the wealthier city of Coral Gables, its dense and affordable rental housing, its "historic" architecture from the 1920s and 30s, its "efficient" street grid system and "pedestrian friendly" commercial building scales (Duggan 2003). Indeed, there is some evidence that the class composition of East Little Havana is changing. After decades of rising poverty and declining numbers of college-educated residents (Geolytics NCBD), from 2000 to 2010 the share of residents with annual incomes below $\$ 25,000$ decreased from 70 to 63 percent, while people earning $\$ 35,000$ or more increased from 16 to 25 percent (U.S. Census 2010). The number of residents with a bachelor's degree or higher increased from 1,325 in 2000 to nearly 2,100 by 2010 (a 56 percent increase).

Maintaining and enhancing social control over the symbolic territory is therefore both an economic development imperative and integral to the Cuban-American elites' construction of place which, in turn, legitimizes and reinforces their power. The gentrification strategy involves selling the neighborhood to a diverse set of housing and cultural consumers, including middle-class Hispanics from Miami’s suburbs and beyond. For decades, CubanAmericans have controlled the majority of the neighborhood's symbols, territory and planning processes. The processes and forms found in the Little Havana landscape are shaped by a specific sense of "affective belonging" to the territory - the conviction that the neighborhood is a place of Cuban-American heritage and symbolic attachment, in addition to offering potentially lucrative opportunities during the next cycle of real estate investment. The revitalization of East Little Havana has been in the making since the early 1980s when city 


\section{DRAFT UNDER REVIEW BY IJURR: Do not use without permission}

officials issued the first plans to "capitalize on the neighborhood's Cuban flavor" (Dibble 1984, p. 4C). In contrast to the typical disinvestment of inner-city neighborhoods by urban elites (Massey and Denton 1993; Mohl 2001), Cuban-American leaders have "taken care” of East Little Havana.

[Figure 2]

\section{Physical Appropriation: Planning the Cuban Future of East Little Havana}

Besides the fact that at no point since 1970 has the share of owner-occupied housing surpassed 15 percent (Geolytics NBCD; U.S. Census 2010), ${ }^{5}$ East Little Havana stands out within the City of Miami in terms of housing construction (instead of demolition) since the 1970s. Whereas most inner-city neighborhoods lost thousands of housing units, especially rental units, between 1970 and 2000 the five Census tracts comprising East Little Havana gained 2,615 housing units, while renter-occupied units increased by 2,132 (Geolytics NCBD). This investment is partly the result of how persistent immigration has sustained the profitability of low-cost apartment buildings (Winsberg 1979; Leon 2007). But “demand” is not the only force driving Little Havana’s housing development and rehabilitation since the 1960s. In the similarly low-income (and darker-skinned) neighborhoods of Wynwood and Overtown, large-scale investors and developers tend to be those with experience nationally. But in Little Havana there are large- and small-scale, Miami-based and even neighborhoodbased investors, as well as considerable although unknown extent of "incumbent upgrading” by new and long-time property owners (Levy 2002).

Little Havana's housing development is supported by, among other sources, the presence and financial lending of the Little Havana-based and Cuban-American-owned Continental National Bank, whose rating in the most recent "Community Reinvestment Act Performance

\footnotetext{
${ }^{5}$ High rates of renter occupancy are comparable to other central-city neighborhoods.
} 


\section{DRAFT UNDER REVIEW BY IJURR: Do not use without permission}

Evaluation” was “outstanding” (CRA 2006). Moreover, some of Miami’s largest housing development firms led by Cuban-Americans, such as "Condo King” Jorge Perez's Related Group, built up capital by constructing affordable rentals and condominiums in Little Havana during the 1970s (Hemlock 2002; Leon 2007). To shore up losses from the market downturn after 2008, the Related Group not only sought out international markets for new investment but returned to building affordable housing in Little Havana, where its access to government funding is facilitated by relationships with local government (Olorunnipa 2011). The former East Little Havana Community Development Corporation (ELHCDC), founded in 1984 and responsible for building hundreds of moderately priced apartments and condos, embodied the relationship between the formally "public" and "private" sectors of urban development as its board of directors was composed virtually entirely of Cuban-American elites. ${ }^{6}$

Until the collapse of the housing market bubble circa 2008, unprecedented levels of capital investment transformed the built landscape (Shoer-Roth 2005). Between 2000 and 2006, the City approved 38 large-scale projects in Little Havana, representing over \$1 billion in construction, 4,620 housing units, and about 430,000 square feet of office and retail space (City of Miami 2006a). By 2006 about one-fifth of those projects were completed or under construction. During the recent market downturn, Miami-Dade County approved \$478 million in subsidies to build a domed baseball stadium in the center of the neighborhood in $2011 .^{7}$

According to our analysis of property sales data (Miami-Dade Property Appraiser 2005), the average price of single-family homes in East Little Havana increased from about \$92,000 in 2000 to almost $\$ 270,000$ by 2005 , while the median price increased in some Census block groups by as much as 400 percent. The median monthly rent grew from about $\$ 476$ in 2000 to

\footnotetext{
${ }^{6}$ For example, the ELHCDC's president and vice-president were the granddaughter of a former Cuban president and a Cuban-American city commissioner from another district.

${ }^{7}$ The new stadium replaced the Orange Bowl, home to the University of Miami's football team. Its spectacular architecture and gleaming facade contrasts the area's deteriorated apartments.
} 


\section{DRAFT UNDER REVIEW BY IJURR: Do not use without permission}

\$766 in 2010, a 61 percent increase. ${ }^{8}$ The investment driving this price growth was supported by ethnocentric urban planning.

The housing strategy will also focus on the provision of incentives for middle-income Young [Urban] Cuban-Americans (YUCAs) ${ }^{9}$ to purchase older historic homes and renovate them in order to move to the City. This would afford the City an opportunity to facilitate the influx of middle class families into the City while generating more retail activities in the neighborhood for the local small business community. (City of Miami Consolidated Plan, 1999-2004)

The homeownership incentives referred to were provided mostly to private developers and non-profit affordable housing builders, and supplied to any qualifying applicants, not just YUCAs. But the affective connection between policymakers and their community's next generation is clear. City officials planned for the return of Cuban-Americans to Little Havana and YUCAs have been returning as part of a broader influx of younger, "upwardly mobile" residents (Gallagher 1989; Rimer 1990; Clark and Perez 1993). ${ }^{10}$ In 2008, Joe Sanchez, the Cuban-American former commissioner for Little Havana, reflected:

In 1998 we were recovering from a long time when gangs ruled the street. Little Havana was economically flat-lined. I wanted to make the area viable for merchants. [Now] we have YUCAs moving into the area every day because their roots are here. You can get your café con leche. For 7 bucks you have a good time on Calle Ocho, a Cuban sandwich and a pop. You don't have to see gentrification and development as evil.

\footnotetext{
${ }^{8}$ Census tract data on monthly gross rent includes utilities. The 2006-2010 statistics are reported in 2010 inflation-adjusted dollars.

${ }^{9}$ Note the play on words: The yucca vegetable, also known as cassava, is a celebrated part of the CubanAmerican diet and cultural repertoire.

${ }^{10}$ Cubans accounted for more than 70 percent of the increase in college-educated residents described above (U.S. Census 2010).
} 


\section{DRAFT UNDER REVIEW BY IJURR: Do not use without permission}

The evocation of café and pork sandwiches underlines the comprehensive strategy which links individual and community interests. Cultural symbols are mobilized to legitimate gentrification as the reconnection of YUCAs with their roots but also, as we discuss below, a way to broaden the scope of governance to other Hispanics.

\section{Spatial and Symbolic Strategies of Commodification}

Through the memorialization of Cuban-American heritage, Little Havana continues to showcase Cuban-American international geopolitical hegemony (Grosfoguel 1996). In addition, the "new Little Havana" (Shoer-Roth 2005) being created through the placemarketing of lifestyle, heritage tourism and cultural events represents the growing concern of Cuban-American elites with local economic development. The following depicts spatial and symbolic strategies that have been implemented to discipline East Little Havana's insecure spaces, working inward from its margins (Figure 3). In describing the neighborhood's symbolic landscape we focus on key examples of how it functions as a "public landscape of state-sanctioned ideological messages” (Ortega 2006) and as an environment for ritualized practices of the use of public space in order to reinforce norms (see Foucault 2004, pp. 56-67). Although Ortega's analysis is of the "network of signs" created in Cuba by the communist state, we argue that Cuban-American elites in Miami, through their control of local government, similarly use symbolic techniques within a broader strategy to define “community” through the production of space (Lefebvre 1991; Gottdiener 1994).

As the neighborhood transitioned toward redevelopment, the symbolism of Cuban heritage has been powerfully reinforced not only through urban planning for the return of CubanAmericans but also the memorialization of Cuban-American heritage in the built landscape. This includes the construction of Jose Martí Park in the 1970s and the Plaza de la Cubanidad and Maximo Gomez “Domino” Park in the 1980s at a cost of more than \$4 million altogether 


\section{DRAFT UNDER REVIEW BY IJURR: Do not use without permission}

(Santiago 1985). Furthermore, in the last two decades the City of Miami invested additional millions to build, expand or renovate key public spaces and neighborhood parks which heightened Little Havana’s symbolic landscape of Cuban-American identity.

At the center of the Cultural District (Figure 3), where tourists arrive by the busloads to sample Cuban cafecito, buy souvenirs and observe the "ethnic" street life, stands the "Art Deco” Tower Theater which the city purchased and renovated in the 1990s. City officials planned its 2002 rebirth as the centerpiece of a revitalized Latin Quarter. ${ }^{11}$ The former city planning director explained that the "advantage” of this section of Little Havana "is that the genuine Hispanic culture still exists here. That is what we are trying to capitalize on" (Benjamin 1998, p. 1B). Domino Park, considered the heart of the Cultural District because of the daily presence of elderly Cubans and other Latino/as playing dominos, is linked to Tower Theater by a domino-themed "pedestrian plaza” and flanked by a Cuban souvenir store (Figure 4). The Cultural District also features Paseo de las Estrellas, a Hollywood-style starred sidewalk inscribed with the names of Cuban-American and other Latin American celebrities. The blocks of Southwest $13^{\text {th }}$ Avenue extending south from Eighth Street, which in the 1970s was designated Cuban Memorial Boulevard and adorned with monuments to Cuban heroes and the martyrs of the Bay of Pigs Invasion, more recently enjoyed a $\$ 4.6$ million expansion (City of Miami 2005a). These "streetscape improvements" extended the existing boulevard and added ramps for persons with disabilities - to improve access for aging Cuban exiles who are still a powerful voting bloc, particularly in local elections. Considered more than mere symbols, the City of Miami describes these investments in Little Havana as the development of a "pedestrian friendly streetscape" that revitalizes the neighborhood's “urban character” (Ibid).

\footnotetext{
11 The Latin Quarter District, established in 1984, was the city's first attempt to revitalize through touristmarketing (Dibble 1984) and was succeeded by the Calle Ocho District, described below.
} 


\section{DRAFT UNDER REVIEW BY IJURR: Do not use without permission}

[Figures 3 and 4]

José Martí Park is a significant symbolic marker as well as an initiative of security and control. The Park is located at the eastern edge of Little Havana (Figure 3) along the River's decaying industrial district with a view of downtown's high-rising skyline, under the visible border of Highway 95 which partitions and segregates Miami’s inner city. One of the neighborhood’s major green spaces, Martí Park has long been associated with crime and drug use (Dibble 1984). In the last decade the park has been integrated into the neighborhood's gentrification strategies and processes through its redevelopment and use as a space of remedial intervention. Initially conceived as part of an urban renewal district in 1972, the park took much of its present form after 2001 through multi-million dollar expansions in facilities and programming to serve existing and new residents. In 2008, the city hired celebrity architect Zyscovich who has worked on other city revitalization projects to design a $\$ 11.3$ million gymnasium in Marti Park (Morales 2008).

The strategic location links the redevelopment of the park to investment returns in Little Havana, including the condo towers erected by private developers and the moderately priced housing constructed by non-profit builders. Yet, high rates of poverty and crime in East Little Havana compel city authorities, private developers and building owners to secure their investments. New residential developments are fortified by electric gated entry with telephone intercom and surveillance technologies. The park itself is surrounded by wrought-iron fences, has limited entry and exit points, and its typically vacant benches are made "bum-proof" by hard plastic dividers that prohibit sleeping. Such “environmental designs” have made Martí Park a "defensible space” (Dear and Flusty 1997), at once friendly and hostile. The former commissioner Sanchez insisted that increased use of the park because of the new gymnasium “will assure people that this is a safe city park morning, noon and night” (Morales 2008, p. $3 G)$. 


\section{DRAFT UNDER REVIEW BY IJURR: Do not use without permission}

Public space where the community can gather and share is also the stage for a set of public spatial practices that normalize certain behaviors and $a b$-normalize others. The location of Viernes Culturales (Cultural Fridays) along Calle Ocho straddles the wealthier, west part and East Little Havana (Figure 3). The monthly festival is the primary spatial strategy that is used to enhance the profitability of an emerging "cultural economy” of arts and tourism as well as housing investment. In 2000 artists and a local health clinic created the street festival to promote the arts and health education for Little Havana's residents. Over time commercial interests, including local art galleries, took control of the festival and excluded the health education component (González 2001). In 2006, commissioner Sanchez sponsored a

resolution designating the "Calle Ocho Cultural Specialty District," a special land-use category which increased the number of liquor licenses in the area to boost entertainment consumption during Cultural Fridays (City of Miami 2006b). Sanchez’s policy assistant explained the commissioner's special interest in the event:

Viernes Culturales is one of my boss' babies. The goal was basically to bring people back [to the city]... What's more all-encompassing than arts and culture? [There's] a fellow Richard Florida (2005), for him you'd rather have artists and creative people and little dance classes taken in a loft above some old auto body shop. This is better than a Wal-Mart. Eighth Street is such a major artery [that] if you're coming from Westchester and you're headed to a restaurant on Brickell, you'll see it... this excitement, you know, non-threatening, fun. (Interview March 2008)

In 2001, the Cuban painter Molina opened a studio on this stretch of Calle Ocho in large part because of Viernes Culturales. He explained that the event not only created a space for consumption but "obliged” city authorities to ensure security. 


\section{DRAFT UNDER REVIEW BY IJURR: Do not use without permission}

We knew that through the event we could reach tourists. Last Viernes, the commissioner came with 40 tourists and we saw also tourist investors coming through the studio... In relation to the 'social situation' of the district, we always thought the situation would improve, that we would clean the area anyway and they were well obliged with the Viernes and it worked. (Interviewed October 2008)

The monthly street festival, which showcases both the economic revitalization of the district and the symbolic heart of the hegemonic Cuban-American community, is the principal mechanism for a particular production of space. The commodification of cultural and political heritage is intended to draw YUCAs as well as older Cubans. Beyond these core constituencies, city officials and investors assert the broader appeal of Calle Ocho for Hispanic and non-Hispanic tourists and potential residents.

Existing residents may see it differently. Neighborhood activist Hugo Miranda ${ }^{12}$ explained that "the Viernes attracts those people who came in the 1970s and have their grandkids in [suburban] Kendall and want to come dance son cubano. But they [festival promoters] can't really say they're promoting the neighborhood's artisans because the [mostly] CentralAmerican residents are not invited.” Only vendors of handcrafted arts who pay a \$30 monthly permit are allowed at the festival, which makes it inaccessible to some poorer vendors. Miranda, who is of Mexican-Bolivian descent, argues that there is insufficient community outreach in the events planning, contributing to many residents' sense that Viernes Culturales is not for them. While including some symbols of Central American culture, the festival primarily represents Cuban heritage and power.

In addition to this representational exclusion, in Little Havana there is a also a centralized "hub" in the network of social relations that seeks to shape the self-conduct of residents. In

\footnotetext{
${ }^{12}$ A restaurant kitchen manager, Hugo was born in Los Angeles, raised in Bolivia and has lived in East Little Havana since he met his Nicaraguan wife there in the early 1990s.
} 


\section{DRAFT UNDER REVIEW BY IJURR: Do not use without permission}

this domain of action the objective is not so much to create symbolic spaces and reproduce spatial practices of consumption, but rather to discipline the everyday behavior of the neighborhood's lower-income residents. This governance is made possible by the unique history of Cuban-American power in Miami.

\section{SHEPHERDING THE CUBAN-AMERICAN FLOCK}

Since at least the 1990s, Cuban-Americans have controlled key elected and administrative positions in the greater Miami area (Stepick et al. 2003). They are mayors of several municipalities, have political majorities on city and county commissions, and are directors of key departments and institutions. In 1992 the City of Miami created an administrative apparatus of governance known as Neighborhood Enhancement Teams (NET). Deemed “mini city halls” inside neighborhoods, the NET offices integrate community-based policing and administrative services, operating in and through partnerships with residents, merchants and community organizations. During one city commission meeting, the Cuban-American mayor interrupted the public comments to distinguish the NET system from the Comités de Defensa de la Revolución (CDR), the neighborhood watch groups created by Fidel Castro in 1960 and often described as the "eyes and ears of the Revolution” in Cuba:

Let me just put in the record [that] the exchange has to with the characterization of the program as a committee of barrios which is something very, very distasteful to people in the Cuban community because it's something that was initiated by Castro to exert surveillance and to co-opt and otherwise oppress the people of Cuba and Mr. Urra has responded that he fought against that and that [the NET] has nothing to do with that. There is no oppression here but there is order. (City of Miami 1992)

Cuban-American elites govern Miami with the help of such meaningful "truths" rooted in the history of their exile from the island. This mode of governing rests on pastoral power, which 


\section{DRAFT UNDER REVIEW BY IJURR: Do not use without permission}

is exercised on individuals within a particular community and implemented through the sites and processes by which self-identity and self-conduct are shaped (Foucault 2004; Elden 2007). Pastoral power "demands a certain level of culture, not only on the part of the pastor but also among his flock” (Foucault 1979, p. 240).

In the first two decades of exile in Miami, community leaders' organizational efforts were directed against the communist government of the territory left behind (Portes and Stepick 1993). Pastorship was used to construct Cuban-American identity as one opposed to Castro (Girard and Grenier 2008) through popular mobilizations, dissemination in local Spanishlanguage media, and the many public and private ways that exile ideology is practiced and reinforced daily (Perez 1992; Portes 2005). Cuban-Americans leaders who never experienced the revolutionary upheaval of the 1960s or who were born in Miami nevertheless repeat and ritualize the exile ideology since the community's votes “translate into powerful offices in Tallahassee and Washington and into profitable contracts for local entrepreneurs” (Portes 2005, p. 195). Adhering to the ideology determines "who can claim the protection, social status and economic opportunities that the community can provide” (Ibid, p. 197). In this way, Cuban-American leadership is "not merely a form of power which commands" (Foucault 1982, p. 783) but is based on elites' legitimacy as caretakers of the community. Representative of this thinking is the discourse of Miami's Cuban-American city manager in the wake of a fresh wave of Cuban refugees in 1995: "Our commitment is that we, the Cuban community, will take care of our own... We are willing to sponsor all expenses of our people so they will not be a burden to our taxpayers” (San-Martin and Gibson 1995, p. 18A).

\section{Little Havana's NET of Spatial Discipline}

Paternalistic strategies of social control are carried out through the NET organizational infrastructure, rooted in interpersonal relations within which Cuban-American elites and their grassroots partners in Little Havana are the moral and political authorities. The organizational 


\section{DRAFT UNDER REVIEW BY IJURR: Do not use without permission}

infrastructure includes the city’s Police, Building and Code Enforcement departments, as well as neighborhood associations, some of which also function as crime watch organizations. The NET is a special layer of city government that supports and coordinates these various operations at the neighborhood level and reduces the gap between the institutions of discipline and people. NET’s mission is to “improve the quality of life and business for Miami residents by: facilitating professional, courteous and efficient delivery of municipal services; developing partnerships which bridge the gap between the public and private concerns; and enhancing and revitalizing Miami’s diverse neighborhoods” (NET 2010). Neighborhood enhancement functions through its "double belonging”: helping people and enabling policing and sanction. In its claim to help people and community, the concept of enhancement masks an underlying aim to revive the profitability of land and business. Pablo Canton, who directed the Little Havana NET since its inception until 2012, explained the following when asked about enhancement:

Enhancement is basically to improve the area by whatever means necessary, whether physically, crime problems, problems of vacant and insecure structures - that is a grave problem. You know that the empty houses attract criminal elements that start doing drugs, delinquents, gangs and people that are dangerous for the area. That is what I focus on as the main things so that the area can develop [and] people come to invest. We need a clean area, a secure area. You understand? That people can walk freely, without having to worry about whether someone will assault them. So for me, lo que es la seguridad, security is number one in everything. (Interview March 2008)

The NET's focus on appearances is linked to the Broken Windows theory of crime prevention, which argues that litter, broken windows, graffiti and other “disorders" hinder community trust by signifying that small crimes are tolerated and discouraging social control (Wilson and Kelling 1982; Herbert and Brown 2006). Moreover, the phrase, lo que es la 


\section{DRAFT UNDER REVIEW BY IJURR: Do not use without permission}

seguridad (what makes up security) is Canton's reference to security as an area of knowledge with fluid meanings, ranging from physical safety from assault to the broken windows that imply social disorder.

The "insecure structures" noted by Canton (also known to code enforcers as "illegal units") are not merely illegal in the sense that they were built or modified without permits. City planners have given these structures social and spatial characteristics: they are "generally found in neighborhoods where newer immigrants are concentrated... [and where] economic conditions and cultural factors contribute to property owners creating building additions to accommodate extended families or groups of like immigrants” (City of Miami Consolidated Plan 1999-2004, p. 73). This language and Canton's reference reveal the emphasis on increased code enforcement activity as well as the implicit stigmatization of "illegal units" in relation to recent immigrants, “criminal elements” and otherwise undisciplined city residents. While Miami's building codes are inherited and adopted from standardized state regulations, their local application is shaped by the knowledge and discretion of NET officials and their

neighborhood partners. Operationally, the NET Director explained how enhancement is carried out.

I have a police officer [who] works with me. We cooperate, it's a 'team.' [If] they're selling drugs in a building, I speak with the owner. 'Listen up, we need you to evict the person that is selling.' If the building has a code violation, you know, we play with that: 'Look, you cooperate with us and we won't enforce the law 100 percent.' Because almost all of the... older buildings have some kind of violation, whether it's the stairs are not good or they made an illegal addition on the side, you know, so trabajamos con la persona (we work with the person). 


\section{DRAFT UNDER REVIEW BY IJURR: Do not use without permission}

While in theory a strict regulatory system, in practice code enforcement is infused with complex social considerations such as "enhancement." The flexibility recognized and operationalized in situ by the NET is made possible by the attention and importance given to relationships, implied above in reference to the "team" formed between NET, the police and code enforcement. The person-to-person relation, conducted in a way that appears “horizontal,” between peers, is essential to NET’s neighborhood-level governance.

Maintaining relationships with residents is integral to the work of Little Havana's elected leaders. Commissioner Sanchez’s policy assistant emphasized the importance of language and close contact in his boss' way of governing: “The Spanish-speaking folks... see [the commissioner's] face, a person that is going to give them the right direction (emphasis added). That's why he [has] two full-time people here with 100 percent [focus] on the constituency.” The cultural context of Cuban-American power in a majority Hispanic city enables leaders' use of latinidad to inculcate “appropriate” behavior in residents by helping them to take care of themselves.

One of the NET's means to influence individuals' conduct is by asking residents to "clean up” the area. "We need your help to eliminate the delinquents," reads one pamphlet for the city’s homeless assistance program. The pamphlet links homelessness with delinquency and implores residents not to feed "them.” Instead, residents should report the homeless and refer them toward assistance centers away from the neighborhood. In another example of the importance of relations, NET's management of “the problem of the homeless" involves employing formerly homeless individuals who work at shelters to "make an assessment" of the (homeless) “client's” needs, as Canton explained, since these “ex-homeless” helpers "know well the system and know how to relate." 


\section{DRAFT UNDER REVIEW BY IJURR: Do not use without permission}

The former NET director established his personal presence on the streets. A military veteran, he patrolled the neighborhood in his car or on bike, and has been known to confront drunken homeless men in parks or on sidewalks. He knows most of the homeless or "crack-heads" by name. Pictures of them posted around his office serve the surveillance needs of staff and police officers and also lead to caricatures created through the use of nicknames and storytelling. Such is the case of "Pepin,” a neighborhood drunk, and "Maria Aguacate” a repeat drug offender and prostitute—both of whom resist "placement" elsewhere in the county and return to live in Little Havana. He keeps close relations with "problem” people on the street, regulating their behavior by emptying out beer containers before their eyes or ordering police to search them for drugs. Not only does the NET Director know people but people know him, such as the elderly women at a major senior center who call him mi novio (my boyfriend), the young police officers that call him el padre (the father), and local artists who called him el pintor (the painter), in reference to his hobby of painting the human-sized rooster sculptures that mark key Cuban-American landmarks as well as the entrance to the Calle Ocho district (Krischer-Goodman 2003). Among his colleagues, the Little Havana NET Director is respected as a passionate administrator and a founding contributor to Miami’s NET system.

Self-discipline and surveillance are achieved through interpersonal relations-as the NET Director puts it, "we work with the person"-and the systematic patrolling of the neighborhood by the forces of control. Citizens, as subjects of this Cuban-American territory, are encouraged to watch over the area and report what they see.

\section{Grassroots Partnerships in NET}

A crucial element in the NET organizational infrastructure is the leadership and activism of resident volunteers, many of whom enlist in the city's Citizens on Patrol (COP) program, deemed "the eyes and ears of the working police officer" (City of Miami 2011). Exemplary of such partnerships are volunteer activists such as Rafael Borgen, a middle-aged Nicaraguan 


\section{DRAFT UNDER REVIEW BY IJURR: Do not use without permission}

public housing resident and former captain of the local COP team, and the elderly leaders of the residential association representing a high-rise public housing complex comprised of 790 apartments or almost 9 percent of Miami-Dade County's 9,000 public housing units. This “fixed capital” represents a large investment of public resources and also houses a large concentration of active voters with family members in other parts of the city and county. Former commissioner Sanchez as well as current commissioner Carollo made routine visits to the dining hall of the Senior Center to solicit votes and socialize during special events where they were the "guest of honor" (De Valle 1998; Shoer-Roth 2009). The neighborhood NET office meets regularly with leaders of the residents association, and responds to their persistent requests for code enforcement and police services.

The Cuban-American leaders of one of these residential associations perceive themselves as "caretakers" of the neighborhood, because of their work to improve the grounds of the public housing complex (group interview, April 2008). This includes organizing clean-up efforts, painting stripes on the parking lot, planting trees, planning social events, and even rebuilding sidewalks. The leaders refer to their "self-management" of the community as an exemplary model to be replicated throughout the neighborhood and beyond. The buildings themselves function as structures of security and surveillance as they soar 14 stories above the street and are equipped with "security gates and cameras, perimeter fencing, intercom, card access entry, a part-time security guard, and a grocery store” (MDHA 2010).

Beyond the self-management and securitization of the public housing complex itself, the elderly leaders take to the streets to "teach" other "decent residents" in the neighborhood how to fight the delinquency and indiscipline thought to be the cause of building code violations 


\section{DRAFT UNDER REVIEW BY IJURR: Do not use without permission}

and "quality of life" abuses (City of Miami 2005b). Borgen, ${ }^{13}$ who has volunteered with NET since its inception, explained how participation enables governing.

If I'm a resident and involve myself in the government's missions, then I give an example of how to work with the government, how to cooperate to change this system that exists in the neighborhood. If in front of a supermarket there's drugs, there's drunkenness, then NET sets up meetings there. They tell the families, 'You change your way of conducting yourself or you leave the neighborhood.' Then NET offers resources. 'You're hooked on drugs? We'll take you to a center. And you, a single mother, what do you need for your child?’ That’s how NET works. (Interview, May 2012)

In our respondents' conceptualization, the struggle is not one between economic classes. By attributing personal conduct and neighborhood conditions to the "morality" or "decency" of the individual, certain behaviors and conditions are disconnected from the context of material deprivation and structural inequality in which they occur. As such, the solution is to intervene not in the structural bases of inequality and material deprivation, but upon the subjectivity of others, specifically to show them "how we have to conduct ourselves." In the following exchange, the residential association leader, Ramona, and other members debate the basis of some residents’ apparent disregard for “the rules.”.

Hilda: That clothesline [hung in the front yard] cannot be that way, it's not authorized.

Ramona: Exactly, there you have an indiscipline of the people who live there. I don't know how many times we have told people by where we live that you can’t [do that].

Belinda: These are... immigrants from a poor background that don’t have qualifications to work and then don't have a good salary and have to live in these conditions.

\footnotetext{
13 Born into an upper class Nicaraguan family, Borgen said he moved to Miami in 1983 in order to "help my people," then a rapidly growing number of Nicaraguans seeking political asylum from the Sandinista revolution.
} 


\section{DRAFT UNDER REVIEW BY IJURR: Do not use without permission}

Ramona: I disagree. I can be poor - because I am poor, OK? But I can be an organized person, I can be clean, I can be respectful of the laws and I can be poor.

Hilda: Exactly! One has nothing to do with the other... But who guarantees that these people are aware of the laws, like which laws there are and how to [follow them].

Belinda: That is the work that we have to do with the community, show them which are the laws and how we have to conduct ourselves. (Group interview, April 2008)

The enforcement of codes is the vehicle for re-taking the streets, over which certain residents are considered morally empowered as “decent” people. The means of neighborhood enhancement through the social infrastructure facilitated by NET is thus the enforcement of codes through vigilance by the neighborhoods' symbolic and, in this sense (of signifying their legitimacy), political owners. This ownership is morally supported by the adherence to codes of decency, inscribed as "quality of life" regulations. To the extent that the problem of "the dirtiness, the bottles, the paper, the garbage" is caused by undisciplined citizen-residents ("those are the citizens littering"), the solution is both the education of citizens and a kind of citizenship education. Education focused on "the basics," as Ramona explained, includes learning about building and "quality of life" codes that are otherwise inconsistently and

leniently enforced. Here the force of the interpersonal relation as the crucial mechanism for both space- and self-management is clear.

Educate people! When our association works with the Miami Police, we go to the neighborhoods. We talk to people, and these things we're telling you [about codes], we say it in those places. You have to get out to the streets! Because when you have in a neighborhood thousands of decent people living there, but 10 delinquents are enough to eliminate the tranquility of those thousand beings, you have to denounce the delinquent! And the police tell you, 'Call us. You have to identify [them].' (Ramona) 


\section{DRAFT UNDER REVIEW BY IJURR: Do not use without permission}

Mauricio, an elderly Central American man who lives in another public housing tower, describes the efforts of his “citizen patrol” unit in particularly moral and spatial ways.

With the Miami Police we go out, try and unite all... the decent people to do the same thing [as Ramona], citizen patrol, to try to combat [delinquency]. If we do not unite the good ones, we allow the bad ones to have power, to take space - [Ramona: the control!]. When they see that they are surrounded they start to adapt and disappear.

\section{PASTORAL POWER AND DECENTRALIZED GOVERNANCE}

Exemplary of broader trends of neoliberal urban restructuring (Brenner and Theodore 2002), Miami’s inner-city neighborhoods are governed in a decentralized fashion, at increasingly local scales, through partnerships with residents that reinforce spatial control. We have not sought to evaluate the extent or the distribution of the costs and benefits of the governing strategies which aim to produce gentrifiable space in Little Havana. Instead, we have drawn attention to the crucial components and operations within the relational ensemble to show how it works in the context of Miami’s Cuban exile community.

Residents are more than mere tools within the decentralized security apparatus. Through their own self-conduct and their intervention upon the conduct of others, residents contribute to the redefinition of citizenship and are stewards of the gentrification economy. Participation in the NET's governing arrangements is based on a particular performance of moral, decent and legitimate inhabitance, established and enforced by Cuban-American elites and their grassroots partners in Little Havana. Some Central-American residents participate by adhering to the rules and adopting the performance. But the ability to shape these ideas of legitimate inhabitance is rooted in the pastoral power monopolized by Cuban-Americans and their political allies (e.g., Nicaraguan exiles). 


\section{DRAFT UNDER REVIEW BY IJURR: Do not use without permission}

Central to pastoral power is the formation of the political subject, the process by which the individual becomes "subject to someone else" as well as "tied to his own identity by a conscience or self-knowledge” (Foucault 1982, p. 781). This was made possible in the CubanAmerican community by the existence of a common cause. Initially a rallying cry against relations with Castro’s Cuba, Cuban-American politics has become increasingly oriented to the local scene. Control over Little Havana, the geographic and symbolic center of the CubanAmerican community, is crucial to the consolidation and preservation of elites' power. The significance of Little Havana goes beyond the electoral support from highly mobilized, elderly voters. Planning for the return of Cuban-Americans to the city through the gentrification of Little Havana is a way to anchor the "moral community" to the increasingly valuable downtown real estate. "We are not destroying history, we're making history," said the district commissioner Sanchez in 2005. Securing their roots gives rise to a more expansive canopy of Cuban-American power: YUCAs and the many other potential constituents (notably other Hispanics) of a gentrified Little Havana.

By speaking in Spanish and being present on the streets and at cultural events, CubanAmerican leaders can extend their primary social sphere, la familia, to the broader "flock" with a stake in the security of the neighborhood, including Hispanic residents, consumers and businesses. A product of the exile experience, Cuban nostalgia and Latinidad exemplified along Calle Ocho form the basis of a Latinized urban consumption experience and a growing “symbolic economy” that supports gentrification by drawing YUCAs, older-generation exiles and other suburbanized Latinos back to the city. Personally guiding investors and tourists to the galleries along Calle Ocho helped to "win the trust of the merchants," as the former commissioner recalled. 


\section{DRAFT UNDER REVIEW BY IJURR: Do not use without permission}

Personal relationship is also the means by which non-Cuban immigrants are "shown the way." In this regard, the discourse and practices of Cuban-American leaders link the molding of self-conduct to the performance of citizenship. When asked how to improve the disorder and dirtiness that she perceived in Little Havana, Ramona, the leader of the residential association, asserted that "the most important thing in terms of citizenship is education of people." The secretary of the Monsignor of San Juan Bosco Church told Del Pino-Allen (2009, pp. 141142), "We Cubans are a major part of Miami, so even if they [Nicaraguans and other Latin Americans] don't want to, they have to learn our ways. I think it is just part of their being here, especially in this area [Little Havana].”

While Cubans have been privileged by favorable U.S. immigration policy, at the neighborhood level membership is attained not so much through formal rights but through a certain performance. In this terrain what matters is "cooperation” with political and legal authorities and the police. As Borgen explained, his local integration through NET rewarded him in other ways: "The [Cuban] authorities, when they saw me cooperating... the interest I had in serving the community, they gave me my papers, they gave me this home, they gave me everything."14 The same is possible for others, reckons Borgen, who is uniquely positioned as a non-Cuban caretaker of non-Cuban immigrants, not only because of his common language and immigrant background. "I've always lived in this area. I know the idiosyncrasies of my people and I identify with them... I don't say the poor, no. They're my poor. God put them in my path, they're mine to serve.” The intimate, personal identification between the leader and his constituents is integral to pastoral power. Constituents may assent, resist or otherwise participate, and in doing so augment the governor's knowledge of the governed. "This form of power cannot be exercised without knowing the inside of people’s

\footnotetext{
${ }^{14}$ According to Borgen, in 1985 the Cuban director of a neighborhood service organization where he volunteered referred him to legal agencies to process his asylum case. More recently, friends in city government facilitated access to public housing.
} 


\section{DRAFT UNDER REVIEW BY IJURR: Do not use without permission}

minds, without exploring their souls... it implies a knowledge of the conscience and an ability to direct it” (Foucault 1982, p. 783).

In these ways, governing crucially involves "the ideological work to reframe who can be a citizen, what a citizen can do and how citizenship is important to claim one's right to the city and the production of that space” (Lepofsky and Fraser 2003, pp. 127-128). Enactment of the neighborhoods" "security" in the ideas, discourse and spatial practice of residents and public officials functions to make space governable "at a distance" by and for those for whom the gentrification of the neighborhood is lucrative and politically expedient. The self-conduct molded and mobilized through the relational exercise of pastoral power obscures the collectively experienced, structural inequalities that shape city life.

\section{References}

Benjamin, Jody A. (1998) Snapping Out Of It: In Little Havana, Road May Be Leading To Recovery. Sun-Sentinel, July 12, 1B, South.

Boyd, Michelle. (2008) Defensive Development: The Role of Racial Conflict in Gentrification. Urban Affairs Review, 43 (6), pp. 751-776.

Brenner, Neil, and Nik Theodore, eds. (2002) Spaces of Neoliberalism: Urban Restructuring in North America and Western Europe. London: Blackwell.

Bridge, Gary. (2001) Bourdieu, Rational Action and the Time-Space Strategy of Gentrification. Transactions of the Institute of British Geographers, 26 (2), pp. 205-216.

City of Miami. (1992) City Commission Meeting Minutes. March 26. Accessed March, 2011 at the City of Miami Clerk Archives.

_ (2004) City of Miami Consolidated Plan, 2004-2009. Community Development Division. Accessed June, 2010 at http://ci.miami.fl.us/communitydevelopment/conplan/.

—. (2005a) Cuban Memorial Boulevard Project, B-30309. Capital Improvements Department. Accessed June, 2010 at www.miamigov.com/bondoversight/pages/.

. (2005b) City of Miami Quality of Life Operations, Department of Code
Accessed $\begin{gathered}\text { June, } \\ \begin{array}{l}\text { Enforcement. } \\ \text { http://www.miamigov.com/Codeenforcement/pages/quality/. }\end{array}\end{gathered}$
http://www.miamigov.com/Codeenforcement/pages/quality/. 


\section{DRAFT UNDER REVIEW BY IJURR: Do not use without permission}

- (2006a) City of Miami Large Scale Development Report: 1995-Present. Planning Department. Accessed April, 2008 at www.miamigov.com/planning/pages/land_development/

(2006b) Meeting Minutes, Department of Planning and Zoning, City Commision Chambers. December 14. Available at http://egov.ci.miami.fl.us/LegistarWeb/frameset.html.

_. (2011) Miami Police Department: Community Relations, Citizens on Patrol. Accessed January, 2011 at http://www.miami-police.org/community_involvement.html.

Clark, Chuck, and Gloria Perez. (1993) Miami Area Gets New Life Returning Residents Revive Little Havana. Sun-Sentinel, March 14, 1B, Local.

Dávila, Arlene. (2004) Barrio dreams: Puerto Ricans, Latinos, and the neoliberal city. Berkeley; Los Angeles: University of California Press.

De Valle, Elaine. (1998) No Sour Notes For This Politician. The Miami Herald, November 8.

Dear, Michael, and Steven Flusty. (1997) The Iron Lotus: Los Angeles and Postmodern Urbanism. Annals of the American Academy of Political and Social Science, 551, pp. 151163.

Del Pino-Allen, Isabel. (2009) La Catedral del Exilio: A Nicaraguan Congregation in a Cuban Church. In Alex Stepick, Terry Rey and Sarah. J. Mahler (Eds.), Churches and charity in the immigrant city: religion, immigration, and civic engagement in Miami, pp. 132-150, New Brunswick, N.J.: Rutgers University Press.

Dibble, Sandra. (1984) City Planners to Pitch Revival of East Little Havana. The Miami Herald, June 14.

Duggan, Ed. (2003) Big changes expected in Little Havana area. South Florida Business Journal, August 8.

Elden, Stuart. (2007) Governmentality, calculation, territory. Environment and Planning D: Society and Space, 25 (3), pp. 562-580.

Eisenhauer, Emily. (2008) Love and Respect for Self and Community: Struggles for Justice in three Miami-Dade Neighborhoods. Research Institute on Social and Economic Policy, Florida International University. July. Available at http://www.risep-fiu.org/wpcontent/uploads/2008/07/ej_exhibitionbooklet_small.pdf.

Feldman, Marcos. (2011) The Role of Neighborhood Organizations in the Production of Gentrifiable Space: Wynwood, Miami's Puerto Rican Barrio. PhD Dissertation, Global and Sociocultural Studies Department, Florida International University. November.

Florida, Richard. (2005) Cities and the Creative Class, New York, NY: Routledge.

Forment, Carlos A. (1989) Political practice and the rise of an ethnic enclave: The CubanAmerican case, 1959-1979. Theory and Society, 18 (1), pp. 47-81.

Foucault, Michel. (1977) Discipline and Punish. London: Allen Lane. 


\section{DRAFT UNDER REVIEW BY IJURR: Do not use without permission}

- (1979) Omnes et Singulatim: Towards a Criticism of Political Reason, in "The Tanner Lectures on Human Values,” Stanford University, October 10, 16, The Tanner Humanities Center, University of Utah.

— (1982) The Subject and Power. Critical Inquiry, 8 (4), pp. 777-795.

(2004) Sécurité, Territoire, Population: Cours au Collège de France (1977-1978). Michel Senellart (Ed.). Paris: le Seuil, Gallimard.

Freeman, Lance. (2006) There goes the 'hood: views of gentrification from the ground up. Philadelphia, PA: Temple University Press.

Gallagher, Colleen. (1989) West Little Havana. The Miami Herald, October 29, 1H, Home \& Design.

Geolytics, Inc. Neighborhood Change Database [NCBD], 1970-2000. Accessed April, 2011 at Florida International University GIS Laboratory.

Gjebre, Bill. (1980) Flagler Street a War Zone. The Miami News, December 17.

Gottdiener, Mark. (1994) The social production of urban space. Austin. University of Texas.

González, Gaspar. (2001) What Art Thou, Little Havana? Viernes Culturales is transforming Calle Ocho -- but into what remains a big question. Miami New Times, September 27.

Girard, Chris, and Guillermo Grenier. (2008) Insulating an Ideology: The Enclave Effect on South Florida’s Cuban Americans. Hispanic Journal of Behavioral Sciences, 30 (4), pp. 530543.

Grosfoguel, Ramon. (1996) Global logics in the Caribbean city system: the case of Miami, in P. L. Knox (Ed.), World cities in a world-system, pp. 156-170, Cambridge University Press.

Harvey, David. (1989) From Managerialism to Entrepreneurialism: The Transformation of Governance in Late Capitalism. Geografiska Annaler, 71 (B), pp. 3-17.

Hemlock, Doreen. (2002) Man with a Mission: Jorge Perez Rose from Building Little Havana Rentals to Cityplace Luxury. Sun-Sentinel, August 30.

Herbert, Steve, and Brown, Elizabeth. (2006) Conceptions of Space and Crime in the Punitive Neoliberal City. Antipode ,38, pp. 755-777.

Jessop, Bob. (2007) From micro-powers to governmentality: Foucault's work on statehood, state formation, statecraft and state power. Political Geography, 26 (1), pp. 34-40.

Jolivet, Violaine. (Forthcoming 2013) Miami la cubaine? Géographie Relationnelle d'une ville-carrefour entre les Amériques. Presses Universitaires de Rennes.

Krischer-Goodman, Cindy. (2003) Go-To Guy For E. Little Havana. The Miami Herald, November 14. 


\section{DRAFT UNDER REVIEW BY IJURR: Do not use without permission}

Lees, Loretta, Tom Slater, and Elvin K. Wyly. (2008) Gentrification. New York: Routledge/Taylor \& Francis Group.

Lefebvre, Henri. (1991) The production of space. Oxford, UK; Cambridge, Mass., USA: Blackwell.

Leon, Hortense. (2007) Workforce Housing Drives Little Havana Revival. Florida Real Estate Journal, April 3.

Lepofsky, Jonathan, and James C. Fraser. (2003) Building Community Citizens: Claiming the Right to Place-making in the City. Urban Studies, 40 (1), pp. 127-142.

Levy, Jaime. (2002) Rehabbing old Little Havana apartments becoming hot ticket. Miami Today, March 14.

Logan, John R. and Harvey L. Molotch. (1987) Urban fortunes: the political economy of place. Berkeley: University of California Press.

Massey, Douglas S. and Nancy A. Denton. (1993) American Apartheid: Segregation and the Making of the Underclass. Cambridge, MA: Harvard University Press.

Miami-Dade Housing Agency. (2010) Public Housing Facilities. Accessed June, 2010 at http://www.miamidade.gov/housing/pub-hous-facilities.asp.

Miami-Dade Property Appraiser. (2005) Property Parcels with Sales Information. Obtained March, 2006 from the Property Appraiser Office.

Mohl, Raymond A. (2001) Whitening Miami: Race, Housing and Government Policy in Twentieth-Century Dade County. The Florida Historical Quarterly 79 (3), pp. 319-345.

Morales, Laura. (2008) High-Tech Workout. The Miami Herald, November 2, Neighbors.

NET. (2010) City of Miami Neighborhood Enhancement Team: Mission Statement. Accessed November, 2010 at http://ci.miami.fl.us/NETS/.

Nijman, Jan. (2000) The Paradigmatic City. Annals of the Association of American Geographers, 90 (1), pp.135-145.

Olorunnipa, Toluse. (2011) From boom to bust and back. The Miami Herald, February 14.

Ortega, Daniel. (2006) "En cada barrio: timocracy, panopticism and the landscape of a normalized community" in Culture Machine, 8. Available at http://www.culturemachine.net.

Pattillo, Mary. (2007) Black on the block: the politics of race and class in the city. Chicago: University of Chicago Press.

Perez, Lisandro. (1992) Cuban Miami. In Alex Stepick and Guillermo Grenier (Eds.), Miami Now! Immigration, Ethnicity and Social Change, pp. 83-108, Gainesville, FL: University of Florida Press. 


\section{DRAFT UNDER REVIEW BY IJURR: Do not use without permission}

Perez-Firmat, Gustavo. (1997) A Willingness of the Heart: Cubanidad, Cubaneo, Cubania. Cuban Studies Association Occasional Paper Series, 2 (7).

Portes, Alejandro. (1987) The Social Origins of the Cuban Enclave Economy of Miami. Sociological Perspectives, 30 (4), pp. 340-372.

- (2005) The Cuban-American Political Machine: Reflections on its Origins and Perpetuation. In Tulchin et al. (Eds.), Changes in Cuban Society since the Nineties, pp. 187206, Washington, DC: Woodrow Wilson International Center for Scholars.

Portes, Alejandro, and Alex Stepick. (1993) City on the Edge: The Transformation Of Miami, Berkeley, University of California Press.

Rimer, Sara. (1990) Miami Journal; The Big Uproar Over Little Havana. The New York Times, October 26.

Rose, Nikolas. (1996) Governing “advanced” liberal democracies. In Andrew Barry, Thomas Osborne and Nikolas Rose (Eds.), Foucault and political reason: liberalism, neo-liberalism, and rationalities of government, pp. 37-64, Chicago: University of Chicago Press.

San Martin, Nancy, and William Gibson. (1995) Miami, Exiles To Pay For Resettling Cuban Boat People. Sun-Sentinel, January 28.

Santiago, Fabiola. (1985) Numerosos Los Homenajes En El Natalicio De José Martí. El Nuevo Herald, January 27.

Sassen, Saskia \& Alejandro Portes. (1993) Miami: A New Global City? Contemporary Sociology, 22 (4), pp. 471-477.

Shoer-Roth, Daniel. (2005) “Adios” For Little Havana? The Miami Herald, October 10.

_ (2009) The Carollos’ Secret Weapon: Their Mom. The Miami Herald, November 24.

Smith, Neil. (1996) The new urban frontier: gentrification and revanchist city. London; New York: Routledge.

Stepick, Alex, Guillermo Grenier, Max Castro and Marvin Dunn. (2003) This Land Is Our Land: Immigrants and Power in Miami. University of California Press.

U.S. Census Bureau. (2000) Educational Attainment, Median Gross Rent and Median Household Income Tables. Accessed at http://factfinder.census.gov, July, 2011.

- (2010) Housing Tenure, Educational Attainment, Median Gross Rent and Median Household Income Tables. American Community Survey Estimation Period 2006-2010. Accessed at http://factfinder.census.gov, March, 2013.

Wilson, James Q., \& George L. Kelling. (1982) Broken windows. Atlantic Monthly Quarterly 249 (3), pp. 29-38. 


\section{DRAFT UNDER REVIEW BY IJURR: Do not use without permission}

Wilson, William Julius. (1996) When Work Disappears: The World of the New Urban Poor. New York: Alfred Knopf.

Winsberg, Morton D. (1979) "Housing Segregation of a Predominantly Middle Class Population: Residential Patterns Developed by the Cuban Immigration into Miami, 1950-74.” American Journal of Economics and Sociology, 38 (4), pp. 403-418. 


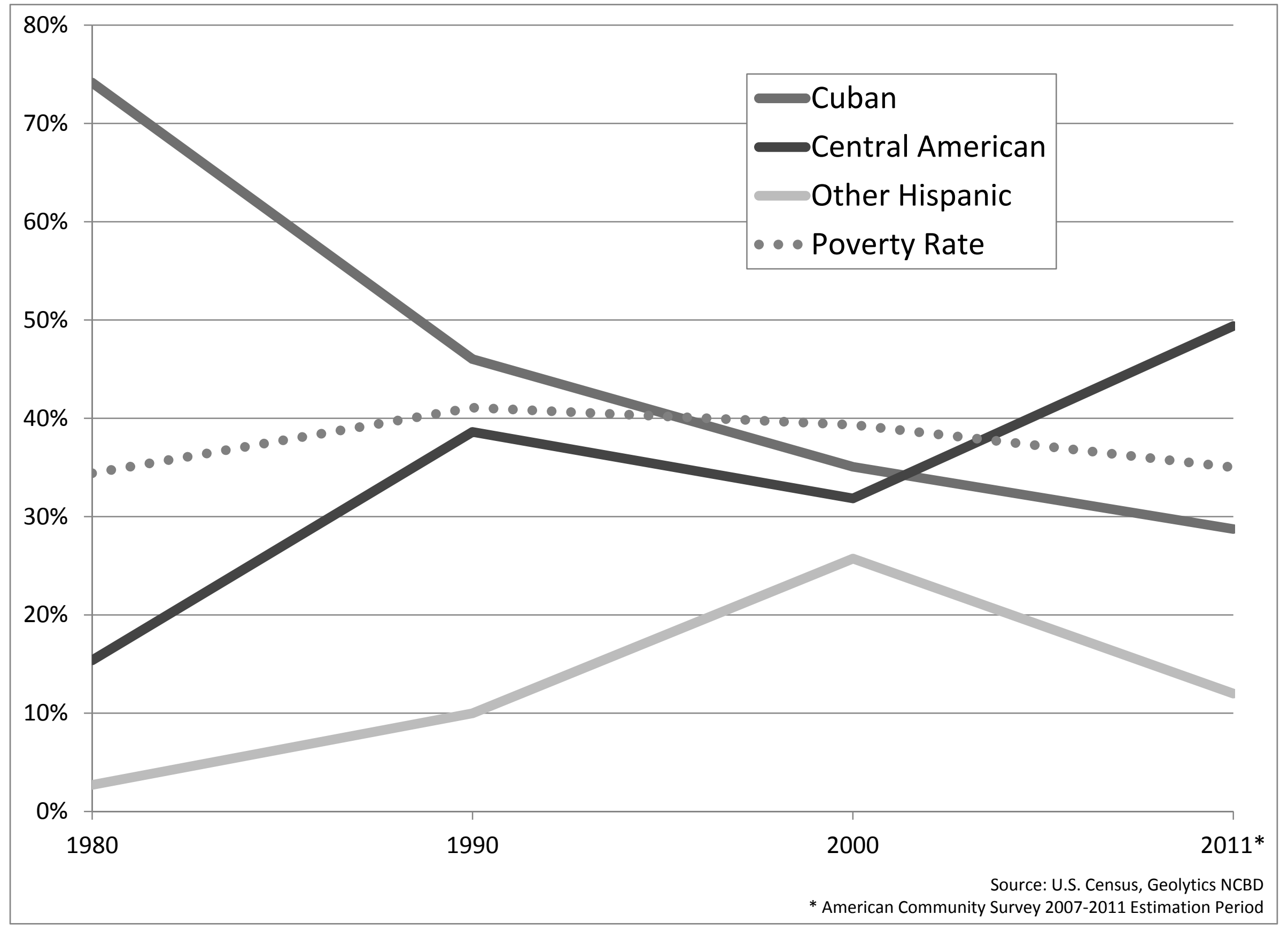


Figure 2

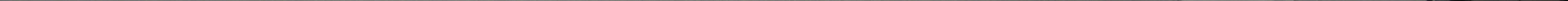




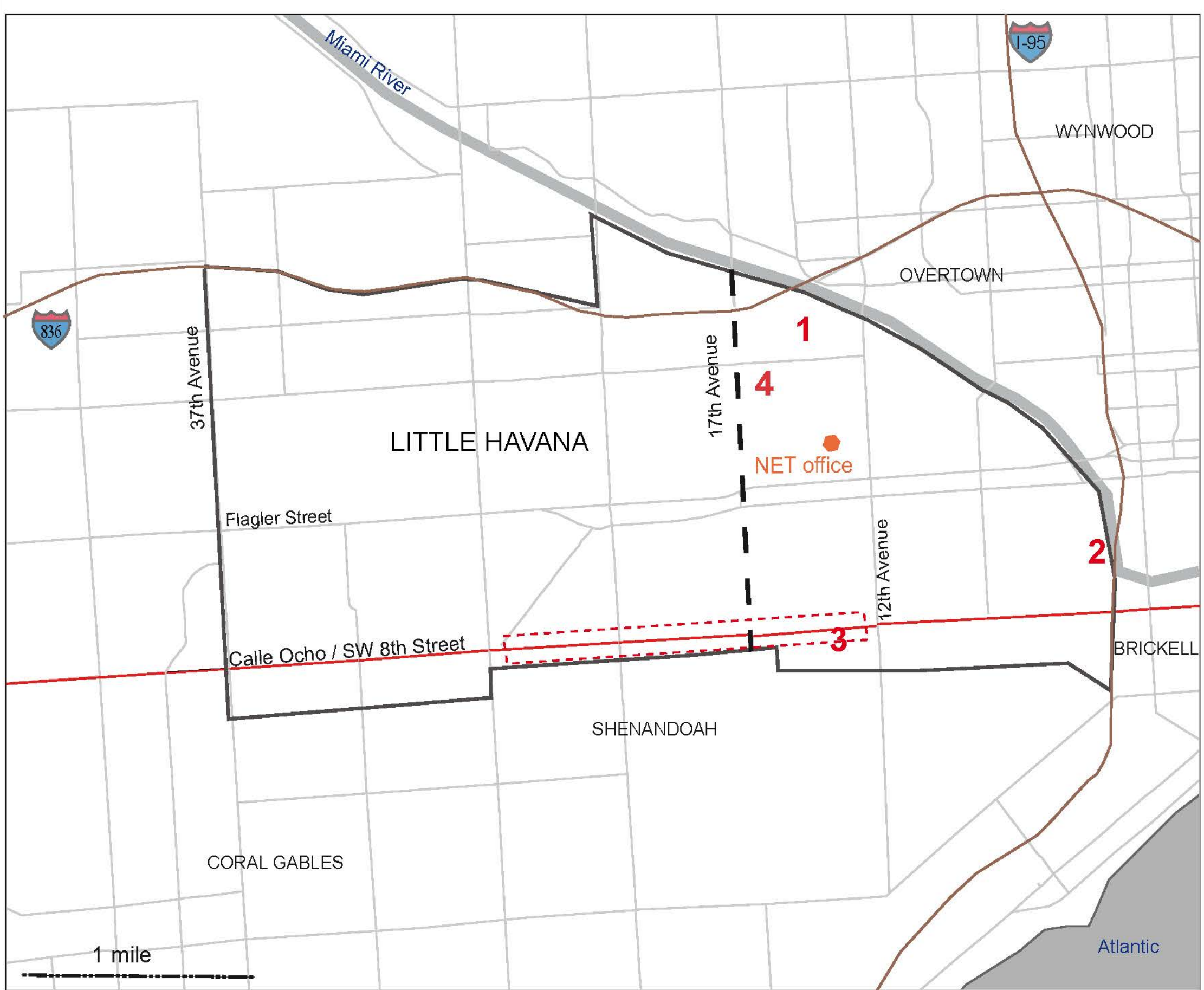

Little Havana in the urbanized Miami-Dade County

\section{LEGEND}

1 Elderly Public Housing

2 Jose Marti Park

3 Tower Theater \& Domino Park

4 'New' Marlins Stadium

_ Calle Ocho

Little Havana

NET boundary

- _ Division between

East and West

Little Havana

Cultural District 
